\title{
Embedded Battery Energy Storage System for Diesel Engine Test Applications
}

\author{
Jianna Niu, George You Zhou, and Tong Wu
}

\begin{abstract}
As is known to all, components of locomotive will be abraded, deformed or damaged after a period of running. In order to ensure the locomotive running stably and extend its lifetime, periodic maintenance and testing must be performed. At present, as a means of load test, water resistance test has been widely used in locomotive diesel engine test field. According to conservative estimates, the static continuous test will accounts $15 \sim 30 \%$ of the energy production through the whole engine life. It will not only cause great waste of energy, but also cause severe corrosion of metal plate. This paper proposes a novel embedded energy storage system used in an energy harvesting demonstration project which is implemented to storage the energy produced during diesel engine test process. This paper also describes the project overall design and the function of key equipment. System simulation and experiment results show that this system is stable and reliable during energy harvesting.
\end{abstract}

Index Terms-Energy harvesting, energy storage, battery, power conversion system, battery management system, diesel engine test.

\section{INTRODUCTION}

Before putting into operation, diesel locomotive engine is required to go through a variety of performance testing: running-in, control test and acceptance test etc. Purpose of the test is to evaluate performance parameters of the diesel engine meeting all the operation requirements required by China Ministry of Railways locomotive maintenance. Generally, the repair cycle for diesel locomotive is 230000 $300000 \mathrm{KM}$ and the overhaul cycle is $700000 \sim 900000 \mathrm{KM}$ [1].

Fig. 1 shows the layout of water resistance test system, which is the essential means of diesel locomotive testing and maintenance at present. The AC electricity power generated by diesel engine test system is converted into DC by rectifier, and finally consumed by the water resistance.

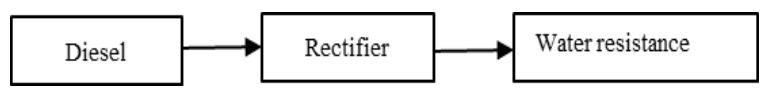

Fig. 1. Diagrammatic layout of water resistance test system for diesel engine test.

According to incomplete statistics, if all the power generated from a medium sized diesel engine testing process is converted to electrical power, which is about $1 / 3$ power that used to manufacture the same diesel engine [2].

Manuscript received January 20, 2015; revised May 4, 2015

The authors are with the National Institute of Clean-and-Low-Carbon Energy, Beijing, China. (e-mail: \{niujianna, zhouyou, wutong\}@nicenergy.com).
Energy harvesting is a rapidly growing industry, storage devices applied in this field are various including capacitor, super capacitor and battery etc. Among them, capacitor is always used for adjusting spike power, super capacitor is used for high energy output with a fast recharge time, and battery is commonly used for sustained power distribution [3]. This paper proposed a novel embedded energy storage system (ESS) which can be applied to diesel engine test platform. As shown in Fig. 2, the system can harvest the energy produced during diesel engine test and charge the harvested energy into energy storage batteries through power conversion system (PCS). Besides, it can also feed the recycled energy to local power grid through a transformer.

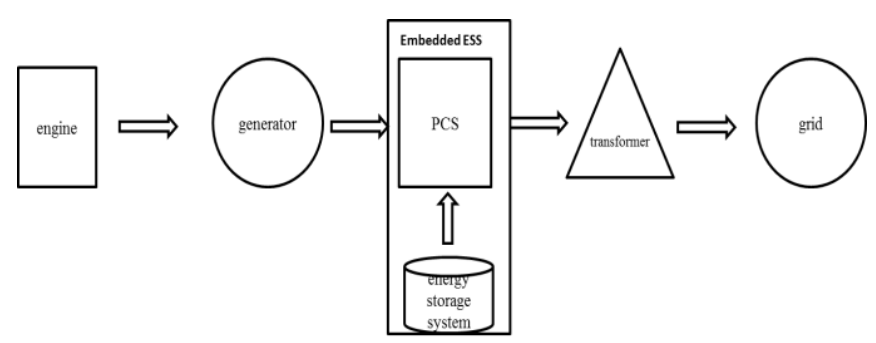

Fig. 2. The embedded energy storage system in energy harvesting demo.

\section{PROJECT DESCRIPTION}

The overall system architecture is shown in Fig. 3. The embedded ESS consists of storage batteries, battery management system (BMS), power conversion system (PCS) and monitoring system. The whole scale of the project is $200 \mathrm{KW} / 560 \mathrm{KW} \cdot \mathrm{h}$, which is composed by two independent sets of $100 \mathrm{KW} / 280 \mathrm{KW} \cdot \mathrm{h}$ energy storage system.

\section{Design AND Functional of EMBEDDEd ESS}

\section{A. Battery Storage System}

Table I lists the performance parameters of four kinds of battery which are commonly used in energy storage field. The table shows that lead-acid battery has the advantages with low cost, long cycle life and high reliability [4], [5], which match the project requirement exactly.

Two groups of lead-acid batteries (350 in series with the specification of single cell $2 \mathrm{~V} / 400 \mathrm{Ah}$ ) is applied to harvest the energy that is produced during diesel engine test. Fig. 4 shows the layout of the battery pack in the container, each $280 \mathrm{KW} \cdot \mathrm{h}$ energy storage battery pack is placed inside a standard 20-foot container, 14 battery blocks are separately set on both side of the container. Enough space between the two rows of battery is reserved for later operation and maintenance. Battery management system (BMS) is located 
on the left side of container. Air duct is located at the back of battery holder; through that air can be conducted to each battery to guarantee batteries can be used at an optimum temperature.

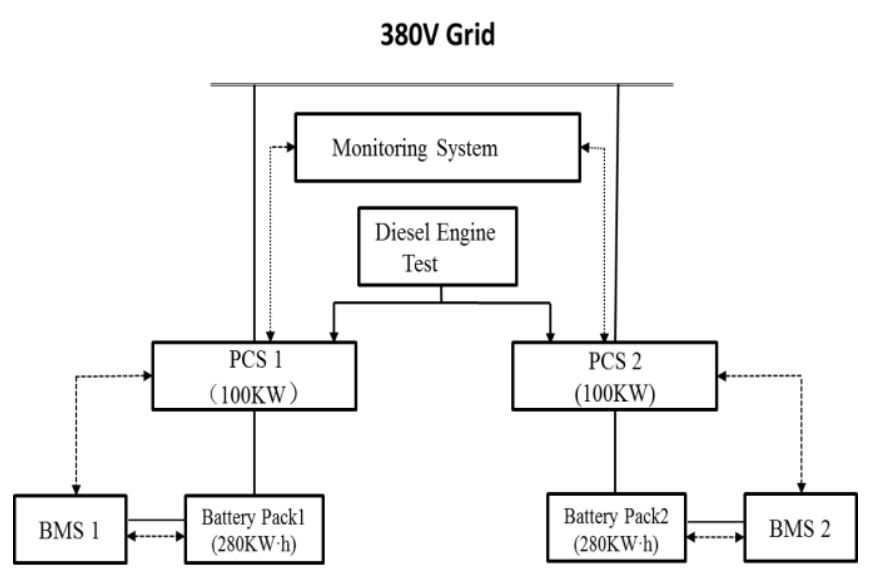

Fig. 3. Architecture of energy harvesting demo.

TABLE I: PARAMETERS OF FOUR POPULAR ENERGY STORAGE BATTERY

\begin{tabular}{lllll}
\hline \hline Performance & Lead-a & Sodium & Flow & Lithium \\
Index & cid & -sculpture & Cell & Battery \\
& Battery & Battery & & \\
\hline
\end{tabular}

\begin{tabular}{|c|c|c|c|c|}
\hline $\begin{array}{l}\text { Working } \\
\text { Voltage (V) }\end{array}$ & 2 & 2 & 1.4 & 3.6 \\
\hline $\begin{array}{l}\text { Power Densit } \\
\text { y }(\mathrm{W} / \mathrm{KG})\end{array}$ & $75 \sim 300$ & $150 \sim 230$ & $120 \sim 150$ & $150 \sim 315$ \\
\hline $\begin{array}{c}\text { Cost } \\
\text { (U.S./KW) }\end{array}$ & $300 \sim 600$ & $1150 \sim 2250$ & $600 \sim 1500$ & $\begin{array}{l}1200 \sim 400 \\
0\end{array}$ \\
\hline $\begin{array}{l}\text { Cycle Life } \\
\text { (Y) }\end{array}$ & $5 \sim 15$ & $12 \sim 20$ & $15 \sim 20$ & $5 \sim 15$ \\
\hline Safety & $\begin{array}{l}\text { Relatively } \\
\text { mature } \\
\text { technolog } \\
\text { y, security. }\end{array}$ & $\begin{array}{l}\text { Ceramic } \\
\text { membrane } \\
\text { is fragile, } \\
\text { easy to } \\
\text { cause fire or } \\
\text { explosion } \\
\text { accidents. }\end{array}$ & $\begin{array}{l}\text { Safety, even } \\
\text { exchange } \\
\text { membrane is } \\
\text { damaged, } \\
\text { the } \\
\text { electrolyte } \\
\text { can be } \\
\text { restored. }\end{array}$ & $\begin{array}{l}\text { Overcharg } \\
\text { e or severe } \\
\text { internal } \\
\text { short } \\
\text { circuit } \\
\text { temperatur } \\
\text { e can lead } \\
\text { to fire } \\
\text { explosion. }\end{array}$ \\
\hline
\end{tabular}

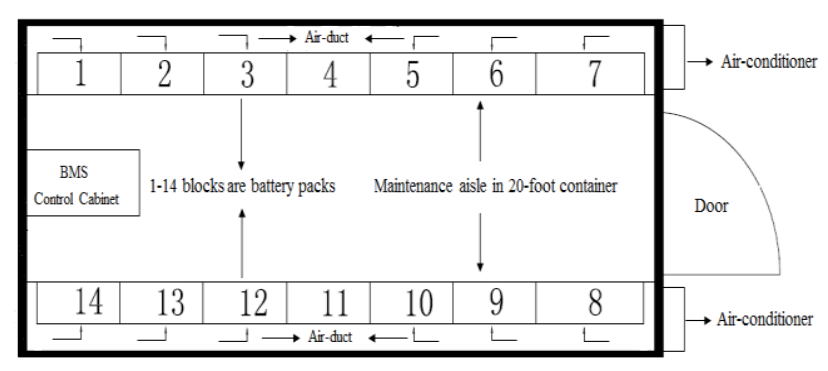

Fig. 4. Layout of $280 \mathrm{KW} \cdot \mathrm{h}$ energy storage battery system

\section{B. Battery Management System (BMS)}

\section{1) BMS architecture design}

The structure of BMS applied in the project is divided into two layers: battery management unit (BMU) and energy system management unit (ESMU). BMU is used to acquire sing battery information including voltage, current, temperature etc. As top layer, ESMU can collect all batteries running data. Besides that, it can also control \& manage BMU to ensure all the single batteries can be used fairly. As shown in Fig. 5, there are totally 14 sets of BMU and 1 set of ESMU is applied. Every single BMU module is able to collect up to 25 battery cell's parameter information. All the information of battery will be send to PCS periodically for the control and protection purposes.

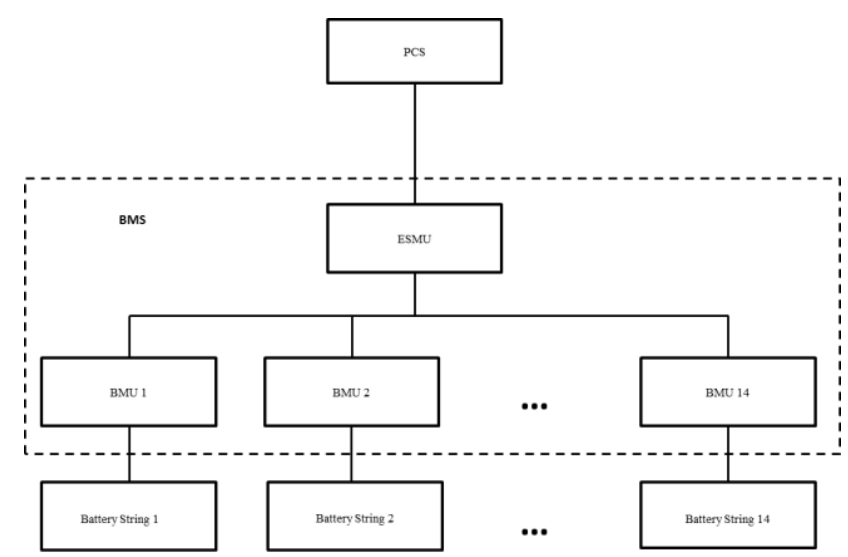

Fig. 5. Architecture of BMS.

\section{2) The function of $B M S$}

The battery management system (BMS) controls how a storage system will be used. In addition, the application of BMS will also offer better robustness for the storage system [6]. As an important part of energy storage battery system, BMS is used to monitor, evaluate, and protect the energy storage batteries [7]-[10]. The major functions of BMS are:

1) Collect battery working data real-timely and upload the information to PCS and energy storage monitoring system;

2) Protect the security of energy storage batteries during charging and discharging;

3) Emergency alarm;

4) Accept monitoring system's operation scheduling and conduct actions accordingly.

\section{Power Conversion System (PCS)}

\section{1) PCS architecture design}

The characteristic of diesel engine test is intermittent as the schedule of test plan and requirement of debugging and repairmen, which require PCS must be extremely durable and can running for months without breaking down. The existing standard PCS will cause much higher voltage ripple when directly interface with storage battery, which will eventually create higher current ripple to shorten the battery life. Fig. 6, Fig. 7 and Fig. 8 embody three possible architectures of PCS combining with energy storage system connecting to AC grid.

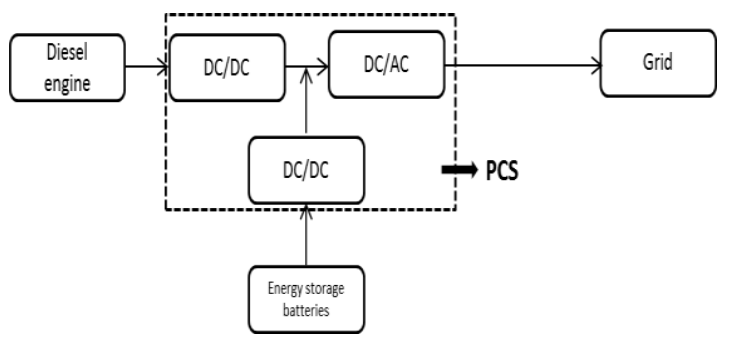

Fig. 6. Architecture of PCS with DC connected energy storage battery. 
As shown in Fig. 6, in order to avoid the damage of high ripple to lead acid batteries, a general solution is to add DC/DC converter between battery system and common DC bus.

Fig. 7 shows the architecture of standard ESS which combining with energy storage system at AC grid system.

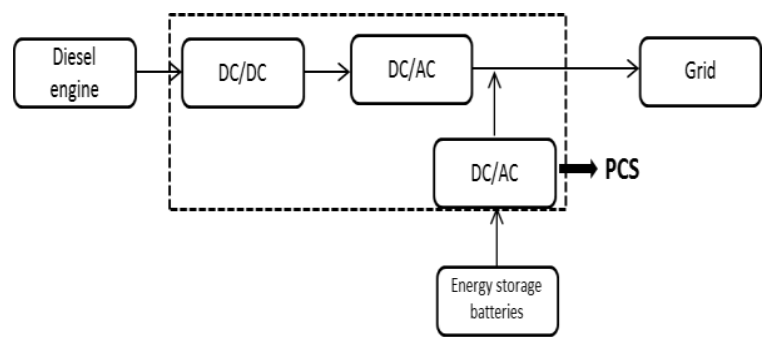

Fig. 7. Architecture of PCS with AC connected energy storage battery.

Instead of the above ESS architecture which combining with energy storage system at grid system by adding DC/DC module or DC/AC module, Fig. 8 presents a novel architecture that internally embedded with energy storage components. The obvious benefit of the proposed scheme is to save one third cost of power conversion system. The realization of the system only need minor software modification on the standard commercial product.

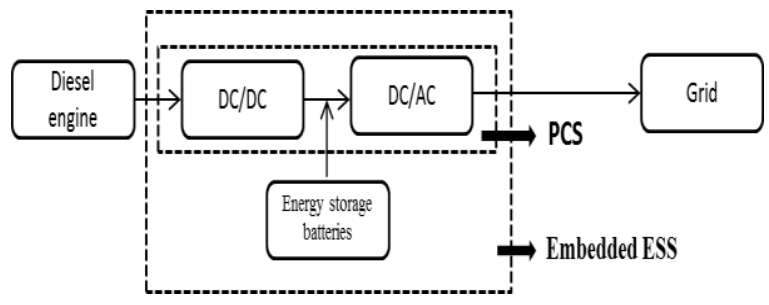

Fig. 8. Architecture of PCS with energy storage batteries embedded.

\section{2) PCS working function}

As a core equipment of the embedded energy storage system, PCS can harvest the energy produced during diesel engine test to large capacity energy storage batteries, beyond that, PCS can also feed the recovered energy back to 380Vpower grid.

PCS has four working modes:

1) Dispatch diesel engine energy to local load directly;

2) Dispatch diesel engine energy for battery charging;

3) Charge batteries from power grid;

4) Discharge batteries to power grid.

\section{3) PCS communication function}

PCS has communication interface with BMS and monitoring system, which can receive battery status data and alarm information from BMS and send to monitoring system. Besides that, PCS can exchange information with monitoring system and conduct user command from operator.

\section{Monitoring System}

\section{1) Function of monitoring system}

Energy storage monitoring system is responsible for supervise and control operation status of the whole energy storage system. It can collect dynamic operation information including diesel engine, energy storage batteries, BMS, PCS and local load, and then make demand accordingly to ensure energy storage system in the best working condition [11], [12].

The main function of monitoring system includes:

1) Display detailed information of measurement device, battery system, BMS and PCS;

2) Remote PCS to do four patterns of power control;

3) Record history operation data.

Fig. 9 shows the wiring interface diagram of monitoring system.

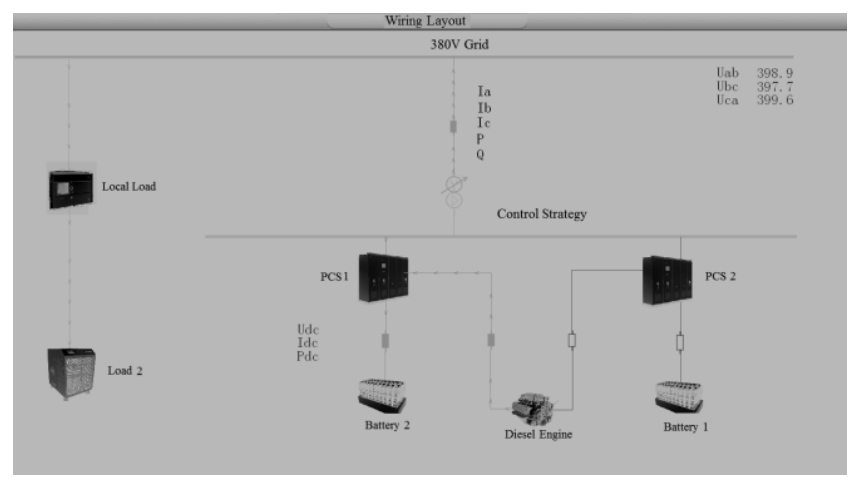

Fig. 9. Surface of wiring layout for monitoring system.

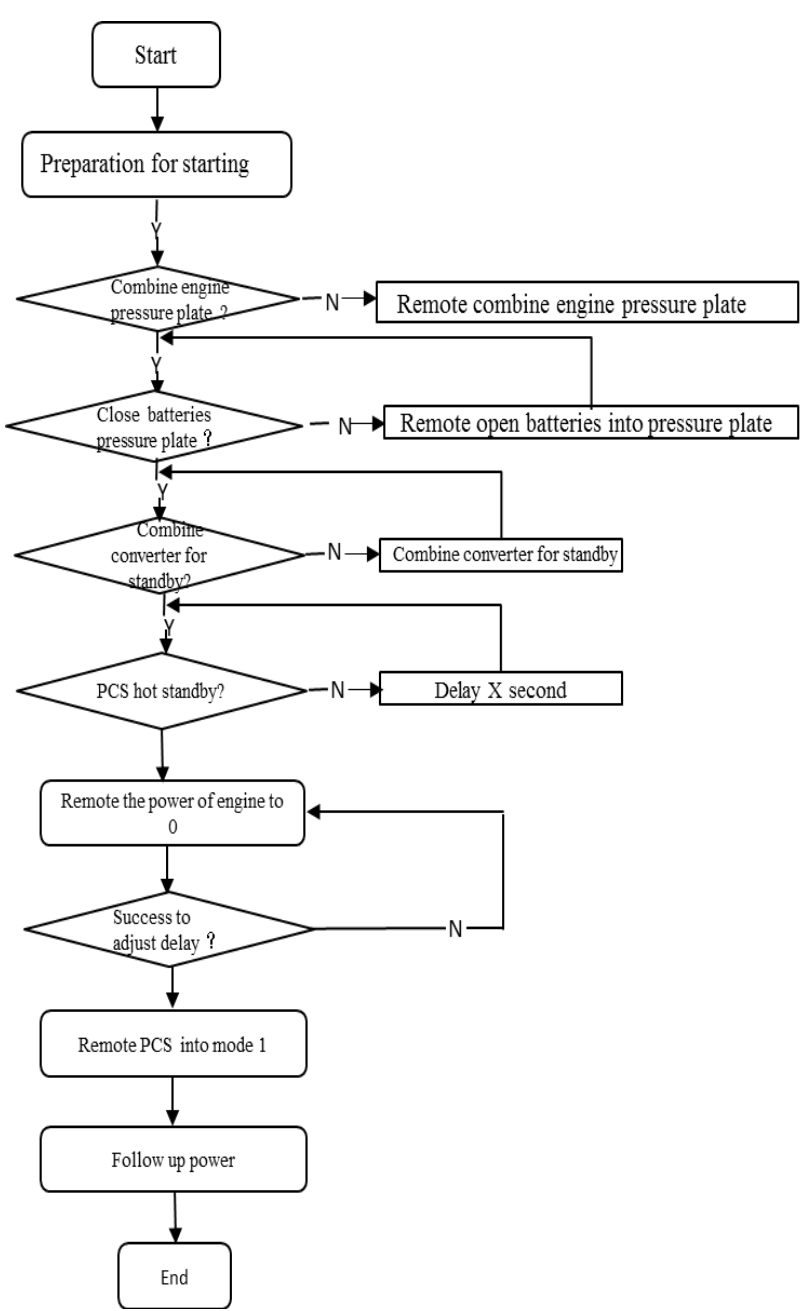

Fig. 10. One of the control strategies of monitoring system

\section{2) Control strategy of monitoring system}

Energy storage monitoring system will adopt different control strategies according to the amount of energy 
produced during diesel engine test and factory load to ensure the energy storage system can be operated stable and reliable. Fig. 10 shows the control strategies for PCS sending back power to power grid.

\section{Simulation AND EXPERIMENTAL RESUlts}

A MATLAB simulation model and a $100 \mathrm{kw}$ prototype are built up and developed in order to verify the stability of the embedded energy storage system (ESS). The simulation and test results are shown as Fig. 11 and Fig.12. Fig. 11 shows the simulation waveform of the ESS running at $80 \mathrm{KW}$ AC load, the results demonstrate that the system is stable and reliable.

1) Stage I: Grid provides $100 \%$ AC load current.

2) Stage II: With the increasing of ESS's output power, AC load get lower energy from grid.

3) Stage III: ESS provides $100 \%$ power to AC load.

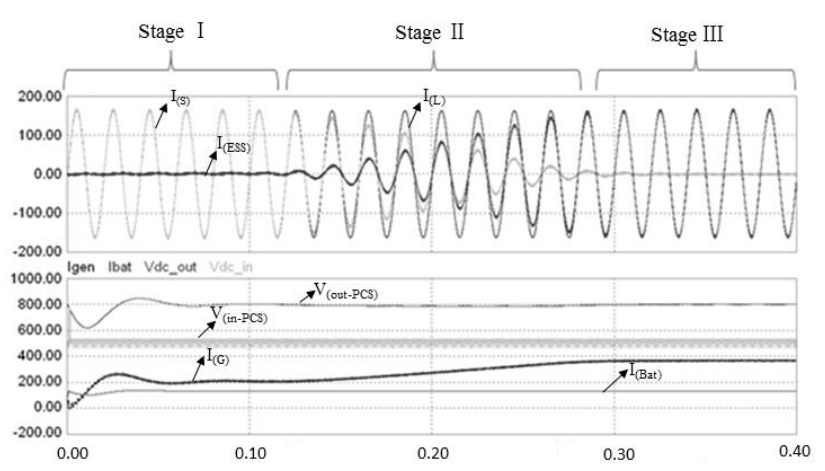

Fig. 11. Simulation waveforms of energy storage system.

In the above part of Fig. $11, \mathrm{I}_{(\mathrm{ESS})}$ is the $\mathrm{AC}$ side output current of ESS; $I_{(S)}$ is the current that power grid provides to local load; $\mathrm{I}_{(\mathrm{L})}$ is the actual consumption current of AC load. In the figure below, $\mathrm{I}_{(\mathrm{G})}$ is the output current of diesel engine; $\mathrm{I}_{\text {(Bat) }}$ is the charging current of battery system; $\mathrm{V}_{\text {(out-PCS) }}$ is input voltage of the battery system; $\mathrm{V}_{\text {(in-PCS) }}$ is DC input voltage of the energy harvesting system.

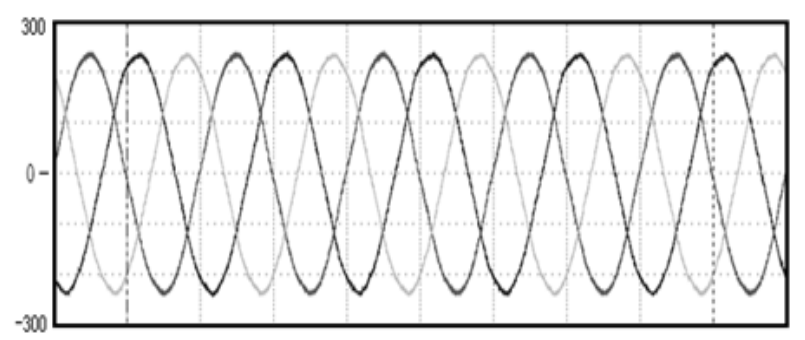

Fig. 12. The AC side current of $100 \mathrm{KW}$ prototype.

\section{CONCLUSION}

With the rapid development of economy, resource shortage and environmental pollution has become an important factor that will restrict the progress of human society. Since that, the development of efficient energy storage device for renewable energy harvesting is particularly urgent. This paper firstly proposed a novel embedded energy storage system applied to diesel engine test platform for energy recovery. Secondly, the system architecture, composition of equipment and its function are introduced. Finally, the simulation and experiment results demonstrate that the system runs stable and reliable in the energy harvesting process. The application of proposed system can effectively solve the energy waste problem during diesel engine test and benefit other similar industrial field.

\section{ACKNOWLEDGMENT}

I appreciate Dr. You Zhou and Tong Wu for their help during my research work. All the R\&D work was greatly supported by National Institute of Clean-and-Low-Carbon Energy (NICE).

\section{REFERENCES}

[1] Y. G. Shi, "Market analysis on overhaul equipment manufacturing of railway diesel locomotive engine," Railway Locomotive \& Car, vol. 27, no. 2, pp. 49-52, April 2007.

[2] S. M. Li, "Study on power electronic technology for renewable energy feedback to grid," Application of Electronic Technique, vol. 4, pp. 38-44, April 2002.

[3] G. Quirk. Reaping the benefits of energy harvesting. Design Applications. [Online]. p. $1 . \quad$ Available: http://www.electropages.com/2011/04/mouser-reaping-benefits-energ y-harvesting-greg-quirk/

[4] M. Gavin and W. G. Hurley, "Battery management system for solar energy applications," in Proc. the 41st International Universities Power Engineering Conference, Newcastle upon Tyne, 2006, pp. 79-83.

[5] S. Y. Liu and X. Zhang, "Survey on energy storage battery in renewable energy distributed generation system," Chinese Journal of Power Sources, vol. 36, no. 4, pp. 601-605, July 2012.

[6] Y. Zhou, T. Li, and L. J. Lu, "Study on the application of monitoring and protection system for large capacity battery energy storage station," Electric Engineering, vol. 5, pp. 43-46, Jun. 2013.

[7] L. N. Pei, Z. Huang, and D. X. Dong, "A hierarchical management system for energy storage batteries," Energy Storage Science and Technology, vol. 3, no. 4, pp. 416-422, Jun. 2014.

[8] S. Q. Zhou, L. Y. Kang, and B. G. Cao, "Optimization of energy storage system in solar energy electric vehicle," Acta Energiae Solaris Sinica, vol. 29, no. 10, pp. 1278-1282, Sep. 2008.

[9] J. G. Liu and J. H. Zhou, "Study on storage battery device used for consumer," Electrical Application, vol. 27, no. 13, pp. 65-68, Nov. 2008.

[10] S. L. Li and G. X. Yao, "Research on ultra-capacitor/battery energy storage in wind/solar power system," Power Electronics, vol. 44, no. 2, pp. 12-14, Sep. 2010.

[11] Y. Liu, W. S. Huang, and T. B Yu, "Information modeling and implementation of monitoring and control system in large scale battery energy storage system," in Proc. 9th IET International Conference on Advances in Power System Control, Operation and Management (APSCOM 2012), Hong Kong, 2012, pp. 1-5.

[12] M. T. Lawder, B. Suthar, P. W. C. Northrop et al., "Battery energy storage system (BESS) and battery management system (BMS) for grid-scale applications," IEEE International Symposium on Power Electronics for Distributed Generation Systems, vol. 102, no. 6, pp. 1014-1030, May 2014.

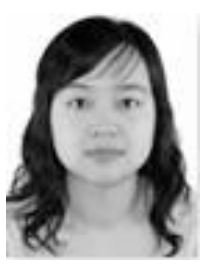

Jianna Niu was born in Luoyang, Henan province, China, December 1981. She received the M.S. degree from the Chemistry and Environmental Engineering School of Changchun University of Science and Technology University in 2007.

She is working for the New Energy Center of Nationa Institute of Clean and Low Carbon Energy (NICE) since Set. 2012. Her research interests include energy storage system integration, energy storage battery and chemistry material R\&D. 


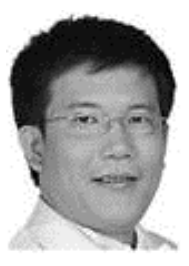

George You Zhou was born in Tangshan, China, May 1973. He received his $\mathrm{PhD}$ degree from Ryerson University in Canada in 2000, master and bachelor degrees from the Department of electrical engineering of Tsinghua University in 1998 \& 1995 respectively with major in power electronics and motor control.

As a senior principle scientist and certified 1000-plan talent, he had been working for the New Energy Center of National Institute of Clean and Low Carbon Energy (NICE) since Dec. 2011. Before joined NICE, he used to work for Honeywell in Canada as a senior principle engineer more than 12 years.

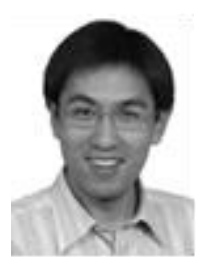

Tong Wu was born in Beijing, China, November 1981 He received the M.S. degree from the Electrical Engineering School of Beijing Jiaotong University in 2007 with major in power electronics and AC drives.

As a lead engineer, he is working for the New Energy Center of National Institute of Clean and Low Carbon Energy (NICE) since Oct. 2012. Before joined NICE, he used to work for ABB drives and VESTAS more than 6 